\title{
A WORLD OF WATER
}


Peter Boomgaard - 9789004254015

Downloaded from Brill.com04/26/2023 10:38:19AM via free access 


\section{E R H A N D E L I N G E N \\ VAN HET KONINKLIJK INSTITUUT \\ VOOR TAAL-, LAND- EN VOLKENKUNDE}

240

\section{A WORLD OF WATER \\ Rain, rivers and seas in \\ Southeast Asian histories}

Edited by

PETER BOOMGAARD

KITLV Press

Leiden

2007 
Published by:

KITLV Press

Koninklijk Instituut voor Taal-, Land- en Volkenkunde

(Royal Netherlands Institute of Southeast Asian and Caribbean Studies)

PO Box 9515

2300 RA Leiden

The Netherlands

website: www.kitlv.nl

e-mail: kitlvpress@kitlv.nl

KITLV is an institute of the Royal Netherlands Academy of Arts and Sciences (KNAW)

Cover: Creja ontwerpen, Leiderdorp

ISBN $906718294 X$

(C) 2007 Koninklijk Instituut voor Taal-, Land- en Volkenkunde

No part of this publication may be reproduced or transmitted in any form or by any means, electronic or mechanical, including photocopy, recording, or any information storage and retrieval system, without permission from the copyright owner.

Printed in the Netherlands 


\section{Table of contents}

Preface

vii

Peter Boomgaard

In a state of flux

Water as a deadly and a life-giving force in Southeast Asia

\section{Part One Waterscapes}

Heather Sutherland

Geography as destiny?

The role of water in Southeast Asian history

Sandra Pannell

Of gods and monsters

Indigenous sea cosmologies, promiscuous geographies and

the depths of local sovereignty

Manon Osseweijer

A toothy tale

A short history of shark fisheries and trade in shark products in twentieth-century Indonesia

Part Two Hazards of sea and water

James F. Warren

A tale of two centuries

The globalization of maritime raiding and piracy in Southeast Asia at the end of the eighteenth and twentieth centuries 
Greg Bankoff

Storms of history

Water, hazard and society in the Philippines, 1565-1930

Part Three Water for agriculture

Robert C. Hunt

Communal irrigation

A comparative perspective

Willem Wolters

Geographical explanations for the distribution of irrigation institutions

Cases from Southeast Asia

Jan Wisseman Christie

Water and rice in early Java and Bali

Franz von Benda-Beckmann

Contestation over a life-giving force

Water rights and conflicts, with special reference to Indonesia

Part Four Pure and impure water; Health and disease

\section{Foong Kin}

The role of waterborne diseases in Malaysia

Okke Braadbaart

Privatizing water

The Jakarta concession and the limits of contract

Anton Lucas and Arief W. Djati

The politics of environmental and water pollution in East Java

About the authors

Index 


\section{Preface}

Books have their fortunes. This book started life as a workshop organised from 14-16 June 2001 as one of the features of the KITLV 150-year jubilee. Upon the request of the board of KITLV, the topic of the workshop was prepared by a small committee consisting of Franz von Benda Beckmann, Willem Wolters and myself. The idea behind it was that the theme of the workshop should reflect both the various disciplines represented by the members of the KITLV and the two geographical areas covered by the Institute's charter - Southeast Asia and the Caribbean. However, as not all the speakers invited to deal with the Caribbean could make it to the workshop, it was decided not to include that region in the book.

The theme chosen was 'water', a topic of great importance everywhere, but perhaps particularly in Maritime Southeast Asia, with its long shorelines in relation to its landmass, and with the enormous expanses of sea surrounding Island Southeast Asia and abutting the shores of Mainland Southeast Asia. This is a theme that, according to the committee, could be addressed fruitfully by scholars specialized in disciplines as far apart as cultural anthropology, economy, fisheries studies, geography, history, and medicine. Water, in several respects a necessity of life, is at the same time a very dangerous element, and it was thought that it should be possible to present these facets of water under the various disciplinary angles, thus constituting a kaleidoscopic image of water in Southeast Asia. It is, of course, up to the reader to judge whether this collection of studies succeeds in presenting such an image.

One of the disadvantages of such a collection is that it never can be complete, and that some people will be disappointed because their pet aspect is lacking. Another drawback is that such a book by its very nature cannot have a conclusion. However, it is hoped that the advantages of the novel approach chosen here outweigh the disadvantages.

This volume is also part of the EDEN (Ecology, Demography and Economy in Nusantara) project of the KITLV, which was established to investigate the environmental history of Indonesia. It goes without saying that the presence or absence of water is an environmental factor of the greatest importance, a topic that is elaborated upon in many contributions to this book. 
Various developments have slowed down the preparation of this volume. For several reasons it was not possible to include all contributions to the workshop, while one article in this volume has been written specifically for the book. Some delay was caused by the fact that the intended co-editor was unable to fulfil the tasks he had taken upon himself. Most authors have shown admirable patience during the long gestation period.

Let me finish by conveying my thanks to those institutions that have funded the workshop and the book. This is of course in the first place the KITLV itself, while in addition funding has been obtained from the Netherlands Organisation for Scientific Research (NWO), the Leiden University Fund (LUF), and the Royal Netherlands Academy of Arts and Sciences (KNAW). 